\title{
Crassostrea virginica shells record local variation in wastewater inputs to a coastal estuary
}

\author{
Carolyn J. Kovacs ${ }^{1}$, Joshua H. Daskin ${ }^{2,3}$, Heather Patterson ${ }^{1}$, Ruth H. Carmichael ${ }^{1, *}$ \\ ${ }^{1}$ Dauphin Island Sea Lab, 101 Bienville Boulevard, Dauphin Island, Alabama 36528, USA \\ ${ }^{2}$ MB 0193 Brandeis University, Waltham, Massachusetts 02454, USA \\ ${ }^{3}$ Present address: School of Marine and Tropical Biology, James Cook University, Townsville, 4811 Queensland, Australia
}

\begin{abstract}
We measured $\delta^{15} \mathrm{~N}$ values in the acid-insoluble organic portion of shells from Crassostrea virginica transplanted at increasing distance from a major wastewater treatment plant in Mobile Bay, Alabama. To determine whether $\delta^{15} \mathrm{~N}$ in shell material recorded local spatial variation in wastewater influence, we compared $\delta^{15} \mathrm{~N}$ in newly deposited oyster shell to $\delta^{15} \mathrm{~N}$ values in wastewater effluent and in suspended particulate matter in receiving waters. We compared $\delta^{15} \mathrm{~N}$ values in shell to $\delta^{15} \mathrm{~N}$ in adductor muscle and whole tissues to determine the isotopic relationships between shell and soft tissues for this previously untested species. $\delta^{15} \mathrm{~N}$ values in oyster shell reflected differences in wastewater influence relative to distance from the wastewater treatment plant within $38 \mathrm{~d}$ of transplanting. $\delta^{15} \mathrm{~N}$ values in shell were enriched by $2.4 \%$ compared to available foods, consistent with a trophic shift from food source to consumer. $\delta^{15} \mathrm{~N}$ values in shell also were significantly correlated with $\delta^{15} \mathrm{~N}$ values in soft tissues, but were enriched by $1.9 \%$ compared to whole tissues and $0.8 \%$ compared to adductor muscle. Overall, $\delta^{15} \mathrm{~N}$ values in oyster shell were a better proxy for adductor muscle than whole tissues. If applied with care, oyster shells provide an ecologically and commercially meaningful wastewater detection tool that may be effective over relatively short spatial and temporal scales. $\delta^{15} \mathrm{~N}$ values in shell material may be particularly useful to enable anthropogenic source tracing and refine food web reconstructions in areas with remnant shells where oysters or other bivalves have been severely depleted or already lost.
\end{abstract}

KEY WORDS: Nitrogen $\cdot$ Stable isotopes $\cdot$ Bivalve $\cdot$ Anthropogenic $\cdot$ Oyster

\section{INTRODUCTION}

Many bivalves are sedentary suspension feeders that incorporate environmental elements into their tissues and reflect environmental influences, particularly relative to the composition of their food sources (Alexander \& Young 1976, Fukumori et al. 2008). This attribute renders some bivalves useful sentinels of anthropogenic inputs such as wastewater (Lake et al. 2001, Shriver et al. 2002, Carmichael et al. 2004a). Wastewater-derived nitrogen $(\mathrm{N})$ typically has a distinct stable isotope $\left(\delta^{15} \mathrm{~N}\right)$ signature that is conveyed to suspended particles in receiving waters and into primary consumers such as bivalves (Carmichael 2004, Martinetto et al. 2006, Piola et al. 2006). Stable isotope ana- lysis, therefore, has been applied to trace wastewater $\mathrm{N}$ through food webs and help define the spatial extent of wastewater influence on ecosystems (McClelland et al. 1997, Martinetto et al. 2006).

Typically, stable isotope ratios in soft tissues such as adductor muscle or whole tissue composites have been used to trace anthropogenic $\mathrm{N}$ sources or reconstruct food webs. Soft tissues, however, provide a relatively short-term indicator of $\mathrm{N}$ source changes or trophic shifts and require careful storage and preservation (Carmichael et al. 2008, Watanabe et al. 2009). Shell material from 2 species of clam, Mercenaria mercenaria and Ruditapes phillippinarum, were recently tested to determine the potential of this more enduring hard tissue to similarly indicate anthropogenic $\mathrm{N}$ sources 
(Carmichael et al. 2008, Watanabe et al. 2009). This approach has proven successful and is promising for the assessment of historical periods or locations in which soft tissues are no longer available or cannot be properly preserved. These studies, however, have traced wastewater sources on relatively broad spatial scales, across embayments. Whether $\delta^{15} \mathrm{~N}$ ratios in shell may be sensitive enough to trace variation in anthropogenic inputs within a single water body has not been tested. The ability of shell to detect differences in $\mathrm{N}$ sources within a relatively limited area could prove useful to identify anthropogenic $\mathrm{N}$ point sources for management and better define the spatial extent of $\mathrm{N}$ source inputs and effects on local biota.

Tracing $\mathrm{N}$ sources or food webs via $\delta^{15} \mathrm{~N}$ ratios in shell also requires defining specific relationships between the $\delta^{15} \mathrm{~N}$ ratios in shell and soft tissues. The reported offset in $\delta^{15} \mathrm{~N}$ ratios between soft tissues and the organic portions of shell has ranged from -0.1 to $2.7 \%$, depending on the species sampled and type of soft tissue analyzed (LeBlanc 1989, O'Donnell et al. 2003, Carmichael et al. 2008, Watanabe et al. 2009; Table 1). Physiological differences in $\mathrm{N}$ assimilation into shell compared to soft tissues were suggested as a possible explanation for this species-specific variation (Carmichael et al. 2008). Bivalves show species-specific fractionation from food sources to tissues, and thickershelled clams exhibit somewhat greater stable isotopic differences between whole soft tissues and shell compared to thinner-shelled mussels (Carmichael et al. 2004b, Valiela 2006; Table 1). More species-specific data are needed to calibrate $\delta^{15} \mathrm{~N}$ values in shell material against values in soft tissues and better resolve the sources of variation between them.
The eastern oyster Crassostrea virginica is a practical species with which to test the ability of $\delta^{15} \mathrm{~N}$ ratios in shell to trace wastewater on a smaller spatial scale and better define species-specific variation in stable isotope ratios. C. virginica is a commercially and ecologically valuable species that inhabits nearshore areas commonly affected by wastewater inputs (Mackowiak et al. 1976, Gregalis 2006, Cerco \& Noel 2007). C. virginica is declining throughout its range along the North American coast from the Gulf of St. Lawrence to the Gulf of Mexico and the West Indies, and data are in demand to inform restoration activities (Luckenbach et al. 2005, Coen et al. 2007). C. virginica also has a distinct shell composition and metabolism compared to other (non-oyster) bivalves in which shell material has been isotopically analyzed. For example, C. virginica shell is primarily comprised of calcite, while clam shell is typically aragonite based (Galtsoff 1964, Price et al. 1976, Fritz 2001), and differences in shell structure are typically associated with differences in amino acid composition in the organic portion of shell (Galtsoff 1964, Fritz 2001, Kobayashi \& Samata 2006). Furthermore, the type of shell structure formed in bivalves can vary seasonally, with age, and between sites (Fritz 2001). Oysters like C. virginica also have a relatively rapid metabolism and higher assimilation capacity for foods compared to other bivalves (Hammen 1969, Bayne \& Newell 1983). All of these differences can affect $\delta^{15} \mathrm{~N}$ values in target tissues (Michener $\&$ Lajtha 2007, Piola et al. 2006; Table 1). Hence analysis of the $\delta^{15} \mathrm{~N}$ ratios in oyster shell may be useful to help resolve sources of variation in $\delta^{15} \mathrm{~N}$ values among bivalve species in general as well as define wastewater effects on oyster biology, marketability, and restoration success (e.g. Daskin et al. 2008, Carmichael \& Kovacs 2010).

Table 1. Comparison of data from studies that compared $\delta^{15} \mathrm{~N}$ values in the organic portion of bivalve shell to values in soft tissues. We report the mean difference between $\delta^{15} \mathrm{~N}$ values $( \pm \mathrm{SE})$ in soft tissue and shell $\left(\delta^{15} \mathrm{~N}_{\text {tissue-shell }}\right)$, type of soft tissue used for comparison, and method of shell processing for each study. Positive $\delta^{15} \mathrm{~N}$ values represent lighter $\delta^{15} \mathrm{~N}$ values in shell compared to soft tissues. Modified from Carmichael \& Kovacs (2009)

\begin{tabular}{|c|c|c|c|c|}
\hline Species & $\delta^{15} \mathrm{~N}_{\text {tissue-shell }}$ & Soft tissue & $\begin{array}{c}\mathrm{CaCO}_{3} \\
\text { removal method }\end{array}$ & Source \\
\hline Crassostrea virginica & $\begin{array}{l}-0.8 \pm 1.7 \\
-1.9 \pm 1.9\end{array}$ & $\begin{array}{l}\text { Adductor muscle } \\
\text { Whole tissues }\end{array}$ & $\begin{array}{l}\text { Acidification } \\
\text { Acidification }\end{array}$ & $\begin{array}{l}\text { Present study } \\
\text { Present study }\end{array}$ \\
\hline Ruditapes philippinarum & $1.1^{\mathrm{a}}$ & Whole tissues & Acidification & Watanabe et al. (2009) \\
\hline Mercenaria mercenaria & $\begin{array}{l}2.4 \pm 0.3 \\
1.0 \pm 0.8^{\mathrm{a}} \\
0.7 \pm 0.8^{\mathrm{a}} \\
0.2 \pm 0.7^{\mathrm{a}}\end{array}$ & $\begin{array}{l}\text { Whole tissues } \\
\text { Adductor muscle } \\
\text { Foot } \\
\text { Mantle }\end{array}$ & $\begin{array}{l}\text { Acidification } \\
\text { Acidification } \\
\text { Acidification } \\
\text { Acidification }\end{array}$ & $\begin{array}{l}\text { Carmichael et al. (2008) } \\
\text { O'Donnell et al. (2003) } \\
\text { O'Donnell et al. (2003) } \\
\text { O'Donnell et al. (2003) }\end{array}$ \\
\hline Artica islandica & $2.7^{\mathrm{b}}$ & Whole tissues & Dialysis, acidification & LeBlanc (1989) \\
\hline Mytilus edulis & $-0.1 \pm 0.2$ & Whole tissues & Dialysis, acidification & LeBlanc (1989) \\
\hline
\end{tabular}


In the present study, we measured $\delta^{15} \mathrm{~N}$ values in the acid-insoluble organic portion of shells from Crassostrea virginica transplanted at increasing distance from a major wastewater treatment plant (WTP) in Mobile Bay, Alabama. We hypothesized that oyster shell material would acquire and reflect location-specific $\delta^{15} \mathrm{~N}$ values from wastewater in the same manner as soft tissues, but with some variation in stable isotope ratios among tissue types and compared to other species. We tested this hypothesis by comparing $\delta^{15} \mathrm{~N}$ in shell from transplanted oysters to $\delta^{15} \mathrm{~N}$ in wastewater effluent and in suspended particulate matter (SPM) in receiving waters at each transplant site. To determine the isotopic relationship between shell and soft tissues for this previously untested species, we compared $\delta^{15} \mathrm{~N}$ values in shell to $\delta^{15} \mathrm{~N}$ in adductor muscle and whole tissues. These comparisons provide data to define the local spatial scale on which oysters captured and traced anthropogenic wastewater influence in an estuary, the type of soft tissues for which shell material is the most suitable proxy in oysters, and the variation between $\delta^{15} \mathrm{~N}$ values in shell and soft tissues among bivalves in general.

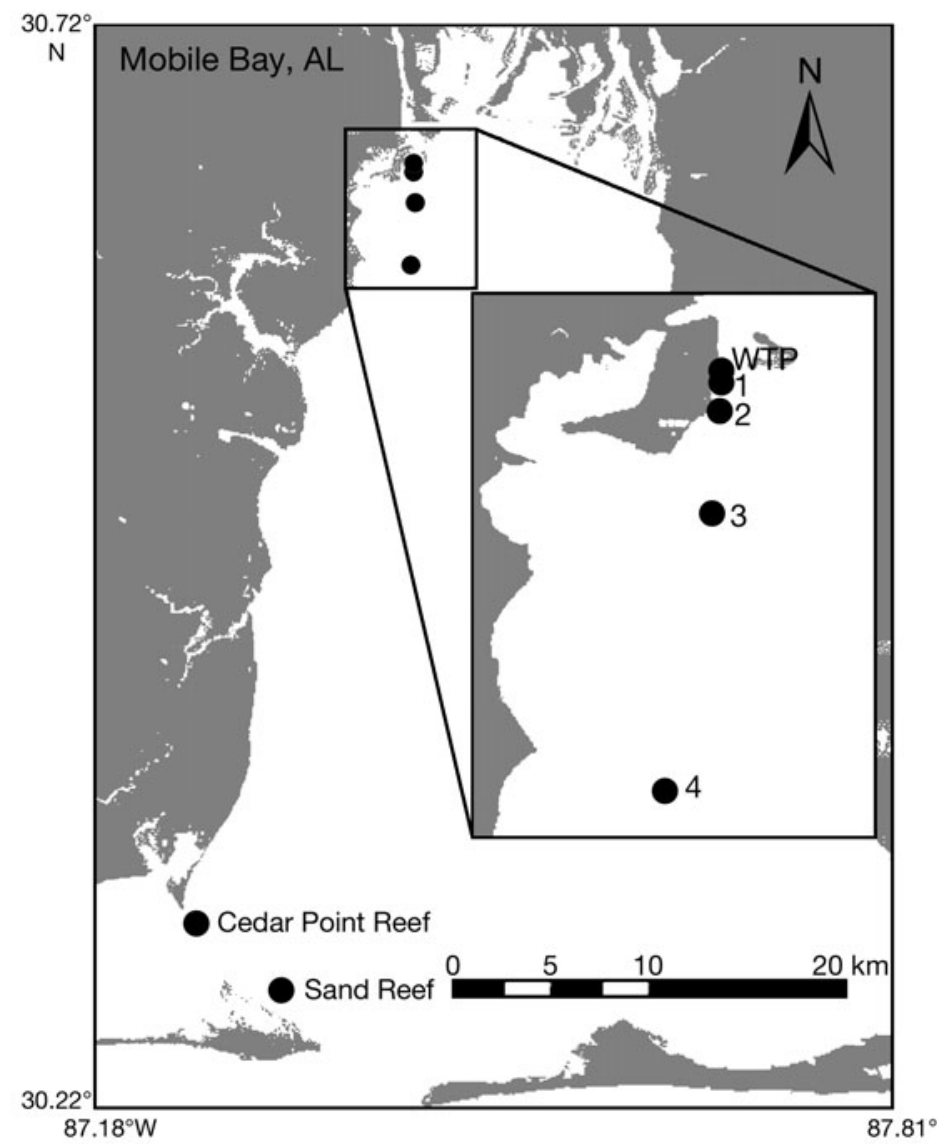

Fig. 1. Sampling sites (•) in Mobile Bay, Alabama, including 4 oyster transplant sites (Sites 1 to 4 ) near the Clifton C. Williams wastewater treatment plant (WTP) and 2 remotely located control sites at Sand Reef and Cedar Point Reef

\section{MATERIALS AND METHODS}

Sample collection. Transplanted oysters: Hatcheryreared oysters (50 to $70 \mathrm{~mm}$ ) were transplanted at 4 sites increasingly distant $(0.07,0.50,2.18$, and $5.68 \mathrm{~km})$ from the Clifton C. Williams WTP outfall in Mobile Bay, Alabama (Fig. 1). Oysters $(n=18)$ were placed in modified aquaculture cages, with 2 pairs of cages deployed at each site on fixed moorings. The outer margins of each shell were marked with permanent ink prior to transplanting to distinguish new shell growth at each transplant site from hatchery growth (Carmichael et al. 2004c, Daskin et al. 2008). Oysters were collected after $38 \mathrm{~d}$ in the field. Growth rates of oysters used for this study ranged from $0.15 \pm 0.01$ to $0.26 \pm 0.06 \mathrm{~mm} \mathrm{~d}^{-1}$ (Daskin et al. 2008). Additional detail on how oysters were obtained, transplanted, and maintained in the field is presented in Daskin et al. (2008).

Control oysters: To distinguish wastewater-derived $\delta^{15} \mathrm{~N}$ values from hatchery and open-water values, we sampled oysters of similar size from the hatcheryreared stock prior to transplanting and from native stock at 2 sites, Cedar Point Reef and Sand Reef, in the middle to lower portions of Mobile Bay (distant from the municipal WTP; Fig. 1).

Effluent and SPM. WTP effluent and SPM in receiving waters were sampled, stored, and processed as reported by Daskin et al. (2008). Briefly, WTP effluent was collected directly from the holding tank immediately prior to release into the outfall pipe on the first and last days of sampling. SPM was taken from water sampled every $2 \mathrm{wk}$ at each transplant site and at the remotely located Sand Reef ( $\mathrm{n}=4$ sampling days for each site). Water samples were pre-filtered through a $200 \mu \mathrm{m}$ sieve in the field.

Sample processing. Oysters were washed with ultrapure water; shells were separated from soft tissues and thoroughly cleaned to remove dirt and residual tissues. Shells were allowed to dry completely under clean conditions before further processing.

Shell material: To obtain shell material reflective of transplant locations, we ground away the outer margin of newly deposited material (shell deposited beyond the transplant ink mark). We captured a comparable shell growth period for native and hatchery oysters by calculating the average marginal shell growth among transplanted oysters $(7.4 \mathrm{~mm} \pm 0.3)$ and removed this same amount of material from the control shells. Marginal shell material was ground away to a powder using a Ryobi dremel tool (no. 81-84-9548) with a contour sanding tube attachment. The shell powder was collected in an acid-washed $20 \mathrm{~cm}$ glass dish and further homogenized using a mortar and pestle. Shell grinding took place in a Misonix workstation (FE 2620) to avoid contamination and aspiration. 
We aggregated 5 to 9 oysters for each sample and prepared 2 replicate samples from each site and hatchery stock for further analysis. Native shells from Sand Reef $(n=2)$ and Cedar Point Reef $(n=1)$ were analyzed as individuals, due to difficulty obtaining live native oysters in Mobile Bay, where oyster reefs are largely depleted. To extract the acid-insoluble shell organic matrix for $\delta^{15} \mathrm{~N}$ analysis, we acidified $1000 \pm 0.7 \mathrm{mg}$ of shell aggregate from transplanted and hatchery oysters and $800 \pm 0.3 \mathrm{mg}$ of shell from single native oysters in $20 \mathrm{ml}$ glass scintillation vials (Carmichael et al. 2008). A volume of 1 to $3 \mathrm{ml}$ of $1 \%$ $\mathrm{PtCl}_{2}$ in $1 \mathrm{~N} \mathrm{HCl}$ was serially applied to the shell samples daily, with gentle periodic mixing until no further bubbling occurred (typically after $7 \mathrm{~d}$ and a total addition of $9 \mathrm{ml}$ of acid). Samples were filtered through a pre-ashed $25 \mathrm{~mm} 0.7 \mu \mathrm{m}$ Millipore GF/F filter and minimally washed with $\sim 6 \mathrm{ml}$ ultrapure water to rinse the filtration apparatus and remove excess acid. To ensure complete extraction, residual shell material in the vials was reincubated in $7 \mathrm{ml}$ of $1 \% \mathrm{PtCl}_{2}$ in $1 \mathrm{~N} \mathrm{HCl}$ over $3 \mathrm{~d}$ and filtered as described above, providing a set of pseduoreplicates to test sample handling.

Soft tissues: Soft tissues were processed for comparison to shell organic matrix by removing guts (as opposed to depuration, to ensure no contamination by unassimilated food particles) and separating adductor muscle from the remaining whole tissues (Daskin et al. 2008). Adductor muscle and whole tissues were chosen because they are the 2 most common bivalve tissue types analyzed for stable isotope ratios among trophic and anthropogenic source tracing studies (e.g. Tieszen et al. 1983, Piola et al. 2006). Tissues were aggregated from 4 randomly selected oysters at each transplant site, so that adductor muscle and whole tissue samples were kept separated.

Effluent and SPM: WTP effluent and SPM samples from receiving waters were filtered as described above, but without washing, to yield at least 2 replicate filters per sample.

Stable isotope analysis. Filters and soft tissues were dried to a constant weight at $60^{\circ} \mathrm{C}$. Soft tissues were ground to a powder using a mortar and pestle. All samples were stored under desiccation before analysis. Samples were analyzed at the UC Davis Stable Isotope Facility by continuous flow-isotope ratio mass spectrometry (CF-IRMS; 20-20 mass spectrometer, PDZ Europa) after sample combustion to $\mathrm{CO}_{2}$ and $\mathrm{N}_{2}$ in an online elemental analyzer (Automatic N and C Analyzer-Gas Solid Liquid, PDZ Europa). Gasses were separated on a Carbosieve G column (Supelco) before introduction to the CF-IRMS. As controls, blank filters and tins were run to detect and, if needed, correct for background $\delta^{15} \mathrm{~N}$ values.
Data analysis. There was no significant difference between the first and second acidifications of shell material. Hence data from these 2 filtrations were averaged to obtain a single $\delta^{15} \mathrm{~N}$ value for each of the 2 replicates. Regression analysis was used to compare the $\delta^{15} \mathrm{~N}$ values in shell to distance from the WTP, and data were log-transformed as needed before analysis. ANOVA was used to test for differences in stable isotope ratios between acidification treatments, between whole tissues and adductor muscle, and among transplant sites (relative to distance from the WTP). Comparison of mean stable isotope ratios in different tissues were made using the complete data set including transplanted, native, and hatchery oysters unless otherwise indicated. A Fisher's protected least significant different (PLSD) test (ANOVA post hoc test) was used to determine the significance of specific differences in stable isotope ratios among transplant sites. To compare the $\delta^{15} \mathrm{~N}$ ratios between shell and adductor muscle or whole tissue, the 2 replicates for each sample were averaged. The $\delta^{15} \mathrm{~N}$ values for native shell and soft tissues were derived by averaging the $\delta^{15} \mathrm{~N}$ value for Cedar Point Reef with the mean values for Sand Reef. Shell and soft tissues were compared using Kendall's $\tau$ correlation test for non-normal data. Error is reported as standard error and was propagated as necessary according to Valiela (2000).

\section{RESULTS}

\section{Tracing wastewater inputs}

Oyster shell acquired $\delta^{15} \mathrm{~N}$ values that reflected location-specific wastewater influences (Fig. 2). The mean $\delta^{15} \mathrm{~N}$ value in WTP effluent was isotopically light $(-3.8 \pm$ $0.3 \%$ ) compared to open water distant from the WTP at Sand Reef (6.8 $\pm 0.6 \%$ ) (Fig. 2, black square and grey dashed line, respectively). Accordingly, $\delta^{15} \mathrm{~N}$ values in SPM available as food for oysters at more distant transplant sites ( $>2 \mathrm{~km}$ away; $6.8 \pm 0.1$ and $6.7 \pm 0.3$, respectively) overlapped with values in SPM at Sand Reef (Fig. 2, open symbols). $\delta^{15} \mathrm{~N}$ values in SPM decreased significantly as wastewater influence increased with proximity to the WTP outfall, with the greatest change in $\delta^{15} \mathrm{~N}$ values occurring within $1 \mathrm{~km}$ of the outfall. $\delta^{15} \mathrm{~N}$ values in the acid-insoluble organic portion of oyster shells reflected those in SPM, also decreasing with proximity to the WTP but showing a mean enrichment of $2.4 \pm 0.3 \%$ (Fig. 2, closed symbols). As with SPM, $\delta^{15} \mathrm{~N}$ values in the shell of oysters transplanted furthest from the WTP outfall were comparable to $\delta^{15} \mathrm{~N}$ values in shell of hatchery $(9.9 \pm 0.2 \%)$ and native oysters $(10.2 \pm$ $0.3 \%$ ) which were not exposed to WTP effluent (Fig. 2, black dashed and dotted lines). 


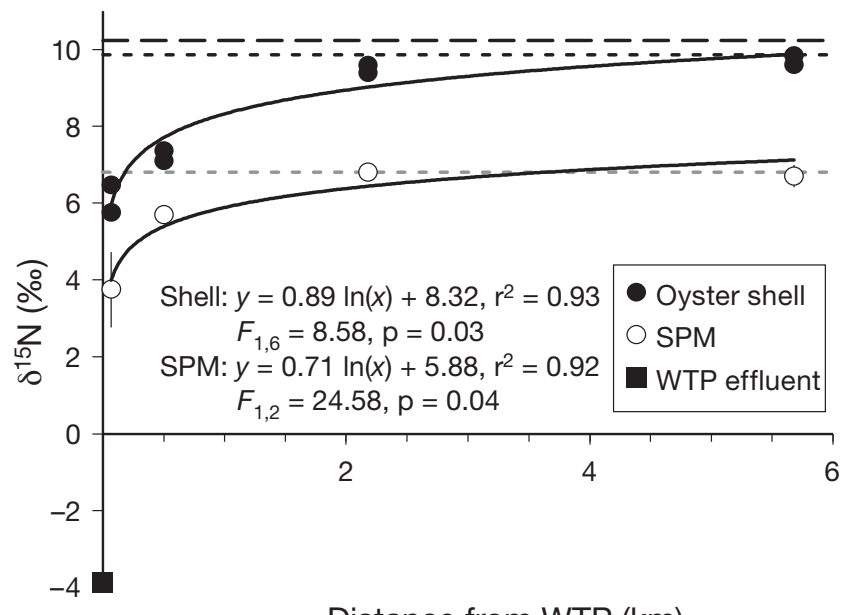

Distance from WTP $(\mathrm{km})$

Fig. 2. Crassostrea virginica. Nitrogen stable isotope ratios in oyster shell, suspended particulate matter (SPM), and wastewater effluent compared to distance from the wastewater treatment plant (WTP). Black dashed and dotted lines show the mean $\delta^{15} \mathrm{~N}$ values in native and hatchery oysters, respectively. The grey dotted line shows the mean $\delta^{15} \mathrm{~N}$ value in SPM at remotely located control sites

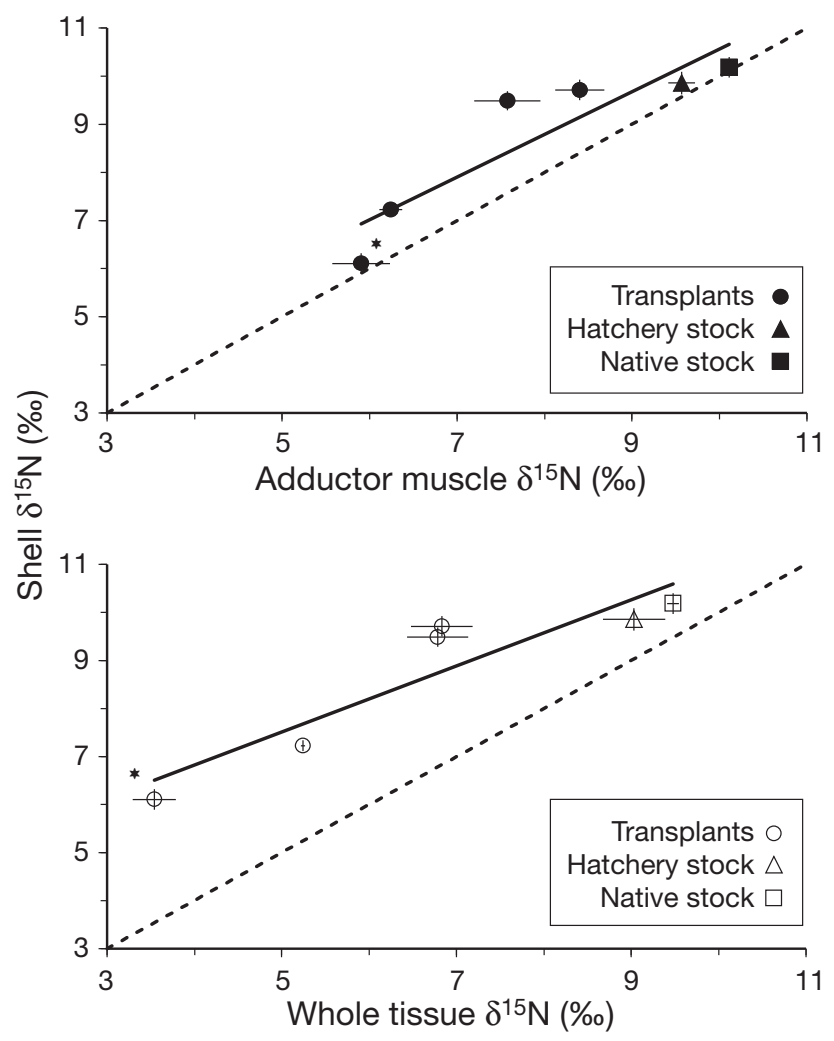

Fig. 3. Crassostrea virginica. Nitrogen stable isotope ratios in oyster shell compared to adductor muscle and whole tissues from transplanted, hatchery, and native stock. Dotted lines indicate the 1:1 line of perfect fit, and the asterisk indicates the sampling site closest to the wastewater treatment plant (Site 1, Fig. 1)

\section{Comparison to soft tissues}

Mean $\delta^{15} \mathrm{~N}$ values differed among tissue types (ANOVA: $F_{2,12}=7.09, \mathrm{p}<0.01$; Fig. 3 ). Mean $\delta^{15} \mathrm{~N}$ values in oyster shell were enriched by $0.8 \pm 1.7 \%$ compared to adductor muscle, but this difference was not significant (Fisher's PLSD: crit. diff. $=1.04, p_{\text {shell, add }}=0.12$ ). $\delta^{15} \mathrm{~N}$ values in shell and adductor muscle, however, were significantly heavier than whole tissues, showing mean enrichment of $1.9 \pm 1.9$ and $1.1 \pm 1.9 \%$, respectively (crit. diff. $=1.04, p_{\text {add, whole }}=0.03, p_{\text {shell, whole }}<0.01$ ).

Mean $\delta^{15} \mathrm{~N}$ values in oyster shell significantly correlated with mean $\delta^{15} \mathrm{~N}$ values in adductor muscle and whole tissues (Kendall's $\tau: \tau=1.0, z=2.8, p<0.01$ for both comparisons; Fig. 3). The mean difference between $\delta^{15} \mathrm{~N}$ in shell and whole tissue increased with proximity to the WTP, deviating more from the 1:1 line at lower $\delta^{15} \mathrm{~N}$ values. The mean difference between $\delta^{15} \mathrm{~N}$ values in shell and adductor muscle, however, was relatively consistent across sites. Although small sample size among native oysters prohibited statistical comparison, transplanted oysters appeared to have an overall greater offset between shell and soft tissues compared to native and hatchery oysters.

\section{DISCUSSION}

\section{Tracing wastewater inputs}

$\delta^{15} \mathrm{~N}$ values in the shell of the eastern oyster Crassostrea virginica reflected differences in wastewater influence relative to distance from a major municipal WTP outfall in Mobile Bay, Alabama. The isotopic shifts we measured in SPM and oysters from the WTP outfall to sites downstream are consistent with the idea that wastewater effluent mixed with and was diluted by open waters (Fig. 2). The logarithmic model describing this relationship (Fig. 2) emphasizes the relatively short distance ( $<1$ to $2 \mathrm{~km}$ ) over which oyster shell acquired and reflected wastewater influence in this estuary. The depleted $\delta^{15} \mathrm{~N}$ values measured in the WTP effluent during the present study were consistent with the lighter values typical of wastewater directly released from major treatment facilities (i.e. Spies et al. 1989, Butler et al. 1997, P. J. Biancani unpubl. data). Similarly, $\delta^{15} \mathrm{~N}$ values in SPM at our open-water sites were comparable to values measured in estuaries throughout the world (Carmichael \& Valiela 2005). Hence these values provided realistic and distinct stable isotopic endpoints across which to test the potential for oyster shell to capture and reflect wastewater inputs to a single estuary. These are the first data to demonstrate that $\mathrm{N}$ stable isotope ratios in bivalve shell material can be used to trace dilution of anthropogenic $\mathrm{N}$ sources on such a small spatial scale. 
Oyster shell showed measurable shifts in stable isotope ratio due to wastewater after a relatively short period of exposure. The $2.4 \%$ enrichment of shell compared to SPM is consistent with a single trophic shift from food source to consumer (Peterson \& Fry 1987, Cabana \& Rasmussen 1994), suggesting that the young adult oysters we transplanted were at or very near equilibrium with their food sources after $38 \mathrm{~d}$ in the estuary. Similar stable isotopic equilibrium periods of 30 to $90 \mathrm{~d}$ have been found for other bivalve species due to a combination of growth and soft tissue turnover (Riera \& Richard 1997, Fila et al. 2001, Carmichael 2004). Soft tissues, however, showed a mean enrichment of 0.5 to $1.3 \%$ compared to SPM, which is less than the 2 to $4 \%$ fractionation previously defined for a trophic shift in this species and other bivalves (Cabana \& Rasmussen 1994, Carmichael 2004, Valiela 2006). This finding suggests our $\delta^{15} \mathrm{~N}$ values in SPM did not accurately reflect assimilated diet among local oysters. Based on our data, an assimilated ratio that was $~ 1.5 \%$ lighter than our bulk SPM would yield fractionation values for oyster shell and soft tissue within the expected trophic range. It is possible that oysters transplanted into Mobile Bay, particularly near the WTP, selected and assimilated an isotopically light component of bulk SPM (Cognie et al. 2001, Ward \& Shumway 2004, Carmichael 2004) or were exposed to higher concentrations of effluent than we captured when sampling bulk SPM. We sampled primarily on incoming and high slack tides when WTP effluent contribution to SPM was likely to be lower. Oysters may have had greater exposure to effluent and subsequently consumed SPM bearing lighter $\delta^{15} \mathrm{~N}$ values on outgoing tides, when we did not sample. It is not likely that our transplanted oysters had not reached equilibrium with their food sources, since $\delta^{15} \mathrm{~N}$ values in the hatchery stock were enriched compared to expected $\delta^{15} \mathrm{~N}$ values in transplants (Fig. 2). Hence oysters not yet at equilibrium would show overenrichment, not the apparent underenrichment we observed in soft tissues.

\section{Comparison to soft tissues}

For Crassostrea virginica, shell organics appeared to be a better proxy for adductor muscle than whole tissues. The significant correlations between $\delta^{15} \mathrm{~N}$ values in shell and both types of soft tissue indicate that all tissues responded similarly to site-specific wastewater influences (Fig. 3). The slope of these correlations and the offsets from the 1:1 line, however, indicate that this relationship was more direct and consistent between shell and adductor muscle than shell and whole tissues (Fig. 3). A similar pattern has been observed for Mercenaria mercenaria, in which organic material in shell showed a greater isotopic offset from whole tissues than individual tissues, including adductor muscle (Table 1). Although there are few studies for comparison, the absolute difference between $\delta^{15} \mathrm{~N}$ values in shell and whole tissues measured for $C$. virginica in the present study $(1.9 \%$ ) is consistent with values reported for other bivalves (Table 1). Since a difference in $\delta^{15} \mathrm{~N}$ values close to or greater than $2 \%$ is large enough to obscure trophic reconstructions, these data suggest organic material in oyster shell is unsuitable as a proxy for whole tissues without application of a correction factor as suggested for hard clams (O'Donnell et al. 2003, Carmichael et al. 2008). Notably, $\delta^{15} \mathrm{~N}$ values in $C$. virginica shell also were consistently heavier than in soft tissues, while in other bivalves shell was typically isotopically lighter (Table 1). These findings highlight the importance of understanding species-specific variation of $\mathrm{N}$ stable isotope ratios in tissues.

Differences in $\delta^{15} \mathrm{~N}$ values among shell organics and soft tissues and among different bivalve species may be due to differences in tissue composition or rate of $\mathrm{N}$ assimilation. Past studies have shown that whole tissue aggregates include organs that may respond very quickly to short-term changes in food supply and environmental attributes, while individual tissues such as adductor muscle may respond more slowly due to metabolic differences among tissues (Lorrain et al. 2002, Piola et al. 2006). As with soft tissues, the microstructure of the shell, including the amino acid components of the organic matrix, can also vary among species, age classes, and environments (Risk et al. 1996, Fritz 2001) and could influence the $\delta^{15} \mathrm{~N}$ values of a shell. Stress associated with environmental change may also cause a shift from shell growth to soft tissue growth in some bivalves (Lewis \& Cerrato 1997, Eversole 2001), such that shell may acquire $\delta^{15} \mathrm{~N}$ values at a slower rate than some soft tissues. This effect in particular may explain the slightly greater isotopic difference between $\delta^{15} \mathrm{~N}$ values in shell and soft tissues of transplanted oysters compared to native and hatchery controls in the present study (Fig. 3). Hence shell organics and adductor muscle may appear isotopically similar because they both reflect integrated longerterm shifts in food resources or environmental conditions, but perhaps for different reasons.

Past study has suggested that slower stable isotope acquisition by tissue such as adductor muscle indicates this tissue is best suited for monitoring $\mathrm{N}$ sources over larger spatio-temporal scales (Piola et al. 2006). Our data, however, suggest adductor muscle and shell in oysters functioned successfully as tracers of anthropogenic wastewater at a relatively small spatio-temporal scale. Location-specific factors that affect dilution and mixing between anthropogenic sources and receiving waters, such as hydrology, residence time, and magni- 
tude of source inputs, along with factors affecting bivalve growth, such as food supply and temperature, will necessarily mediate the scales at which bivalves and their tissues may function as tracers in individual estuaries (Piola et al. 2006, Gustafson et al. 2007). A more complex sampling scheme, therefore, may be needed to capture and describe broad-scale spatial variation even within a single estuary (Andrew \& Mapstone 1987, Underwood 1993). Location- and speciesspecific variation may also mean more or less time is needed to allow sentinel bivalves to reach isotopic equilibrium with ambient food sources and associated anthropogenic inputs of interest (Bosley et al. 2002, Carmichael 2004, P. J. Biancani et al. unpubl. data). For example, studies in seasons or regions where water temperatures or food supplies are lower may require more time due to slower metabolic rates, while studies with younger bivalves may require less time due to faster growth and metabolic rates.

Despite the potential sources of variation, the consistent relationships between $\mathrm{N}$ stable isotope ratios in shell and in WTP effluent demonstrate the utility of this method as an indicator of anthropogenic $\mathrm{N}$ sources. Diligent reporting of methods will likely substantially close gaps in the understanding of reported variation in stable isotope ratios among species, tissue types, and locations (Carmichael et al. 2008, Carmichael \& Kovacs 2010). Future studies could be further refined to account for potential sources of variation among species and tissues by including compound-specific analyses via single-compound mass spectrometry of the shell organic matrix (Risk et al. 1996, Tripp \& Hedges 2004). The whole shell method used here, however, is likely to continue to be useful and appealing because it is relatively accessible for use by ecologists at all levels. Samples can be processed quickly, require relatively simple processing with readily available materials, and, if properly quantified and packaged, can be analyzed at standard commercial stable isotope facilities without specialized calibration (Carmichael et al. 2008, Carmichael \& Kovacs 2010).

\section{CONCLUSIONS}

Oysters and other bivalves provide an ecologically and commercially meaningful wastewater detection tool. Our data indicate that oyster shell, like soft tissues, detected and traced wastewater influence over relatively short spatial and temporal scales. The present study is the first to demonstrate that organic material in oyster shell not only acquired stable isotope ratios that reflected anthropogenic $\mathrm{N}$ sources to local waters, but also were sensitive enough to trace these inputs at a scale of 1 to $2 \mathrm{~km}$ within a single water body. If oyster shell is to be used as a proxy for soft tissues in anthropogenic source tracing and other stable isotope-based analyses, however, it is important to note that shell material may respond more similarly to adductor muscle or other metabolically comparable tissues than whole tissues. A well-defined correction factor may be needed to use oyster shell material as a proxy for whole tissues. This consideration is imperative since the difference between shell and whole tissues may be large enough to confound trophic assessments. This approach is potentially powerful, if applied with care, because it allows the use of transplants or shell analysis alone in areas where oysters and oyster reefs or other bivalves are severely depleted or already lost.

Acknowledgements. This work was funded in part by the National Science Foundation Research Experiences for Undergraduates program (no. OCE-0453973), the University of South Alabama Oyster Restoration Program (NA06NMF 46306708), and the Mississippi-Alabama Sea Grant Consortium (NA06OAR4170078). We also thank the Auburn University Shellfish Laboratory and the UC Davis Stable Isotope Facility for their services. We thank Dr. M. Risk for comments on the initial manuscript. N. Taylor, C. Pabody, and A. Aven provided laboratory assistance.

\section{LITERATURE CITED}

Alexander GV, Young DR (1976) Trace metals in southern Californian mussels. Mar Pollut Bull 14:178-181

Andrew NL, Mapstone BD (1987) Sampling and the description of spatial pattern in marine ecology. Oceanogr Mar Biol Annu Rev 25:39-90

Bayne B, Newell R (1983) Physiological energetics of marine molluscs. In: Wilbur K (ed) The Mollusca: physiology, Vol 4. Academic Press, New York

Bosley KL, Witting DA, Chambers RC, Wainright SC (2002) Estimating turnover rates of carbon and nitrogen in recently metamorphosed winter flounder Pseudopleuronectes americanus with stable isotopes. Mar Ecol Prog Ser 236:233-240

Butler E, Higgins M, Chiapella J, Sung W (1997) Deer Island effluent characterization studies: January 1995-December 1995. Report ENQUAD 97-03, Massachusetts Water Resources Authority, Boston, MA,

Cabana G, Rasmussen JB (1994) Modeling food chain structure and contaminant bioaccumulation using stable nitrogen isotopes. Nature 372:255-257

Carmichael RH (2004) The effects of eutrophication on Mya arenaria and Mercenaria mercenaria: growth, survival, and physiological responses to changes in food supply and habitat in estuaries receiving different $\mathrm{N}$ loads. PhD thesis, Boston University

Carmichael RH, Kovacs CJ (2010) Comment on Watanabe et al. (2009). Mar Pollut Bull 60:314-315

Carmichael RH, Valiela I (2005) Coupling of near-bottom seston and surface sediment composition: changes with nutrient enrichment and implications for estuarine food supply and biogeochemical processing. Limnol Oceanogr 50:97-105

> Carmichael RH, Annett B, Valiela I (2004a) Nitrogen loading to Pleasant Bay, Cape Cod: application of models and 
stable isotopes to detect incipient nutrient enrichment of estuaries. Mar Pollut Bull 48:137-143

Carmichael RH, Rutecki D, Annett B, Gaines E, Valiela I (2004b) Position of horseshoe crabs in estuarine food webs: $\mathrm{N}$ and $\mathrm{C}$ stable isotopic study of foraging ranges and diet composition. J Exp Mar Biol Ecol 299:231-253

> Carmichael RH, Shriver A, Valiela I (2004c) Changes in shell and soft tissue growth, tissue composition, and survival of quahogs, Mercenaria mercenaria, and softshell clams, Mya arenaria, in response to eutrophic-driven changes in food supply and habitat. J Exp Mar Biol Ecol 313:75-104

- Carmichael RH, Hattenrath T, Valiela I, Michener RH (2008) Nitrogen stable isotopes in the shell of Mercenaria mercenaria trace wastewater inputs from watersheds to estuarine ecosystems. Aquat Biol 4:99-111

Cerco C, Noel M (2007) Can oyster restoration reverse cultural eutrophication in Chesapeake Bay? Estuaries Coasts 30:331-343

Coen LD, Brumbaugh RD, Bushek D, Grizzle R and others (2007) Ecosystem services related to oyster restoration. Mar Ecol Prog Ser 341:303-307

Cognie B, Barillé L, Rincé Y (2001) Selective feeding of the oyster Crassostrea gigas fed on a natural microphytobenthos assemblage. Estuaries 24:126-131

> Daskin JH, Calci KR, Burkhardt W, Carmichael RH (2008) Use of $\mathrm{N}$ stable isotope and microbial analysis to define wastewater influence in Mobile Bay, AL. Mar Pollut Bull 56:860-868

Eversole AG (2001) Reproduction in Mercenaria mercenaria. In: Kraeuter J, Castanga N (eds) Biology of the hard clam. Elsevier, New York, p 221-260

Fila L, Carmichael RH, Shriver A, Valiela I (2001) Stable N isotopic signatures in bay scallop tissue, feces, and pseudofeces in Cape Cod estuaries subject to different $\mathrm{N}$ loads. Biol Bull 201:294-296

Fritz LW (2001) Shell structure and age determination. In: Kraeuter J, Castanga N (eds) Biology of the hard clam. Elsevier, New York, p 53-76

Fukumori K, Hideyuki MO, Takahashi D, Okuda N, and others (2008) Bivalve tissue as a carbon and nitrogen isotope baseline indicator in coastal ecosystems. Estuar Coast Shelf Sci 79:45-50

Galtsoff PS (1964) The American oyster Crassostrea virginica. Fish Bull 64:1-480

Gregalis K (2006) Evaluation of the fisheries benefits of oyster reef restoration along a bio-physical gradient in Mobile Bay, Alabama. MS thesis, University of South Alabama, Mobile

Gustafson L, Showers W, Kwak T, Levine J, Stoskopf M (2007) Temporal and spatial variability in stable isotope compositions of freshwater mussel: implications for biomonitoring and ecological studies. Oecologia 152:140-150

Hammen C (1969) Metabolism of the oyster, Crassostrea virginica. Am Zool 9:309-318

Kobayashi I, Samata T (2006) Bivalve shell structure and organic matrix. Mater Sci Eng 26:692-698

> Lake JL, McKinney RA, Osterman FA, Pruell RJ, and others (2001) Stable nitrogen isotopes as indicators of anthropogenic activities in small freshwater systems. Can J Fish Aquat Sci 58:870-878

LeBlanc C (1989) Terrestrial input to estuarine bivalves as measured by multiple stable isotope tracers. PhD thesis, McMaster University, Ontario

- Lewis D, Cerrato R (1997) Growth uncoupling and the relationship between shell growth and metabolism in the soft shell clam Mya arenaria. Mar Ecol Prog Ser 158:177-189

Lorrain A, Paulet Y, Chauvaud L, Savoye N, Donval A, Saout $\mathrm{C}$ (2002) Differential $\delta^{13} \mathrm{C}$ and $\delta^{15} \mathrm{~N}$ signatures among scallop tissues: implications for ecology and physiology. J Exp
Mar Biol Ecol 275:47-61

Luckenbach M, Coen L, Ross P, Stephen J (2005) Oyster reef habitat restoration: relationships between oyster abundance and community development based on two studies in Virginia and South Carolina. J Coast Res 40:64-78

> Mackowiak PA, Caraway CT, Portnoy BL (1976) Oyster-associated hepatitis: lessons from the Louisiana experience. Am J Epidemiol 103:181-191

> Martinetto P, Teichburg M, Valiela I (2006) Coupling of estuarine benthic and pelagic food webs to land-derived nitrogen sources in Waquoit Bay, Massachusetts, USA. Mar Ecol Prog Ser 307:37-48

McClelland J, Valiela I, Michener R (1997) Nitrogen-stable isotope signatures in estuarine food webs: a record of increasing urbanization in coastal watersheds. Limnol Oceanogr 42:930-937

Michener R, Lajtha K (2007) Stable isotopes in ecology and environmental science, 2nd edn. Wiley-Blackwell, Cambridge, MA

O'Donnell T, Macko S, Chou J, Davis-Hartten K, Wehmiller J (2003) Analysis of $\delta^{13} \mathrm{C}, \delta^{15} \mathrm{~N}$, and $\delta^{34} \mathrm{~S}$ in organic matter from the biominerals of modern and fossil Mercenaria spp. Org Geochem 34:165-183

Peterson B, Fry B (1987) Stable isotopes in ecosystem studies. Annu Rev Ecol Syst 18:293-320

Piola RF, Moore SK, Suthers IM (2006) Carbon and nitrogen stable isotope analysis of three types of oyster tissue in an impacted estuary. Estuar Coast Shelf Sci 66:255-266

Price RJ, Thayer GW, LaCroix MW, Montgomery GP (1976) The organic content of shells and soft tissues of selected estuarine gastropods and pelecypods. Proc Natl Shellfish Assoc 65:26-31

Riera P, Richard P (1997) Temporal variation of $\%{ }^{13} \mathrm{C}$ in particulate organic matter and oyster Crassostrea gigas in Marennes-Oléron Bay (France): effect of freshwater inflow. Mar Ecol Prog Ser 147:105-115

> Risk M, Sayer B, Tevesz M, Karr C (1996) Comparison of the organic matrix of fossil and recent bivalve shells. Lethaia 29:197-202

Shriver A, Carmichael R, Valiela I (2002) Growth, condition, reproductive potential, and mortality of bay scallops, Argopecten irradians, in response to eutrophic-driven changes in food resources. J Exp Mar Biol Ecol 279:21-40

Spies RB, Kruger H, Ireland R, Rice DW Jr (1989) Stable isotope ratios and contaminant concentrations in a sewagedistorted food web. Mar Ecol Prog Ser 54:157-170

- Tieszen L, Boutton T, Tesdahl K, Slade N (1983) Fractionation and turnover of stable carbon isotopes in animal tissues: implications for $\delta^{13} \mathrm{C}$ analysis of diet. Oecologia 57:32-37

Tripp JA, Hedges REM (2004) Single-compound isotopic analysis of organic materials in archaeology. LCGC North America 22:1098-1106

Underwood AJ (1993) The mechanics of spatially replicated sampling programmes to detect environmental impacts in a variable world. Aust J Ecol 18:99-116

Valiela I (2000) Doing science: design, analysis, and communication of scientific research. Oxford University Press, New York

Valiela I (2006) Global coastal change. Blackwell Publishing, Malden, MA

- Ward JE, Shumway SE (2004) Separating the grain from the chaff: particle selection in suspension- and deposit-feeding bivalves. J Exp Mar Biol Ecol 300:83-130

- Watanabe S, Kodama M, Fukuda M (2009) Nitrogen stable isotope ratio in the Manila clam, Ruditapes philippinarum, reflects eutrophication levels in tidal flats. Mar Pollut Bull 58:1447-1453 